\title{
Geography Of Stock Returns: Evidence From An Emerging Market
}

Omar Farooq, American University, Cairo, Egypt

Molk Kadiri Hassani, Al Akhawayn University, Ifrane, Morocco

\begin{abstract}
Does location of corporate headquarters matter for stock returns? Do investors prefer to invest in firms located near them? This study aims to answer these questions by using a large dataset of stock returns for firms listed at the Bombay Stock Exchange during the period between 2003 and 2007. Our results show that stock returns of firms show a strong degree of co-movement with stock returns of other firms located in the same city as them. Interestingly, we also show that this degree of co-movement goes down with firms located in the neighboring cities. We also show that stock returns of firms exhibit the least degree of co-movement with firms that are located farther from the neighboring cities. Furthermore, our results show that this degree of co-movement in stock returns is increasing over the period of time. Our results are consistent with prior literature that considers location as an important determinant of stock returns.
\end{abstract}

Keywords: Geography of Stock Returns; Return Co-movement; Local Bias; Geographic Segmentation

\section{INTRODUCTION}

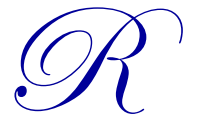

ecent strand of literature documents a strong evidence of positive co-movement in stock returns of firms located in the same city. Anderson and Berachaa (2008), for instance, show that firms headquartered in the same cities experience positive co-movement in their stock returns. They also show that return co-movement diminishes with increase in distance. Similar results are also reported by Pirinsky and Wang (2006). One of the reasons cited for these results is a strong bias in portfolio holdings of investors towards local firms. Prior literature cites several reasons such as asymmetric information, observational learning, and social interactions of investors as some of the explanations for this behavior (Kang and Stulz, 1997; Grinblatt and Keloharju, 2001; Dahlquist et al., 2003; Chan et al., 2005; Brown et al., 2005).

Most of the empirical evidence on co-movement in stock returns is from developed markets. There is not enough evidence showing that such a phenomenon exists in emerging markets as well. Conventional wisdom suggests that due to relatively weak governance and disclosure mechanism, investors in emerging markets should show strong preference for local equities for which they may have more reliable information. "Investors located near a firm can visit firm's operations, talk to suppliers and employees, as well as assess the local market conditions in which the firm operates" (Coval and Moskowitz, 2001). Geographic proximity with headquarters of firms translates into access to more relevant information. Our arguments are consistent with Davis and Henderson (2008) who argue that information advantage arises due to the fact that corporate headquarters are the center of information exchange between firms and its investors. As a result, local investors discover local information before other investors. Therefore, it is intuitive to believe that investors prefer to trade in geographically proximate local firms, thereby causing co-movement of stock returns. In another related study, Feng and Seasholes (2002) demonstrate that trading behavior of individuals is increasingly conditional upon distance and investors who live near a firm's headquarter react in a similar fashion to information while remote investors react differently on aggregate. This would also predict co-movement of stock returns. Another commonly cited argument regarding investing in local stocks is the psychological desire and comfort. This is, especially, true when local brokerage firms have close ties with local corporate executives. Keeping local capital within the community ensures mutual benefits for both, i.e. brokers and local firms (Coval and Moskowitz, 1999). It should also, eventually, result in co-movement of stock returns. 
Contrary to what has been described above, there is an abundance of literature that suggests the opposite. Khanna and Palepu (2000) argue that big firms use their track record and reputation in their established lines of business to gain credibility among investors. As a result, investors are inclined to invest in these nationally recognizable big firms rather than geographically proximate local firms. This would suggest that there should be lower co-movement in stock returns between firms headquartered in the same cities. Furthermore, emergence of information technology should also lower information asymmetry between local and other investors, thereby reducing co-movement in stock returns.

Conflicting arguments regarding co-movement in stock returns makes further examination of the issue an interesting task. The paper aims to explore co-movements in stock returns in India, one of the fastest growing emerging markets. We measure co-movement by time-series sensitivity (beta) of firm's stock returns to stock returns of the portfolio of firms headquartered in the same geographic area as the firm. Using a large dataset of firms listed at the Bombay Stock Exchange, we find that stock returns exhibit high degree of co-movement with firms that are located in the same city as them. Our results also show that this co-movement becomes less pronounced with firms that are located in the neighboring cities. We also document that firm's stock returns exhibit the least comovement with market portfolio, the constituents of which are located the farthest from firm. Our results are consistent with Anderson and Berachaa (2006) who demonstrate that "returns on stocks tend to move not only with returns of same city stocks, but also to a lesser extent with returns on stocks headquartered in proximate cities". They show that return co-movement with portfolios of stocks headquartered in other cities within 100 miles of firm's own headquarter display twice the co-movement with portfolios of stocks headquartered in cities located more than 200 miles away. An interesting finding of our paper is that the co-movement with same city portfolio is increasing over the period of time, while the co-movement with the neighboring cities portfolio and the market portfolio is decreasing over the period of time. This result is surprising because improvement in governance and disclosure mechanisms should decrease information asymmetry and encourage investors to invest in stocks that are located farther away. Prior literature suggests that decrease in information asymmetries leads to lesser home bias in investor's investment decisions (Ahearne et al., 2003).

The reminder of this paper is organized as follows. In section 2, we discuss our data. Section 3 details our methodology and findings. Section 4 presents robustness checks. Section 5 discusses our results and the paper concludes with Section 6.

\section{DATA}

This paper documents the extent to which geography plays a role in stock returns for firms listed at the Bombay Stock Exchange. Our sample consists of all firms for which the monthly stock returns are available for the period between 2003 and 2007. We will, briefly, describe data in the following section.

\subsection{Stock prices and market index}

We extract stock price data and market index data from Datastream. The data for stock prices and market index (SENSEX 30) is obtained for the first and the last day of the month.

\subsection{Headquarter of firms}

We obtain the information about the names of cities in which headquarters of firms are located from Worldscope. This data is used to create portfolios of firms headquartered in the same city and portfolio of firms headquartered in neighboring cities.

\section{METHODOLOGY}

\subsection{Creation of portfolios}

We create two portfolios to measure the effect of distance on co-movement of returns. The first portfolio consists of firms that are located in the same city as the firm itself, while the second portfolio constitutes of firms 
that are located in the neighboring cities. Following Anderson and Beracha (2006), monthly return on same city portfolio is calculated as follows.

$$
R_{\text {City }}=\sum_{\substack{i=1 \\ i \neq j}}^{N_{C}} \frac{R_{i}}{N_{C}-1}
$$

Where $\mathrm{N}_{\mathrm{C}}$ is the number of firms in city and $\mathrm{R}_{\text {city }}$ is the monthly return of portfolio consisting of all firms that are located in same city as firm $\mathrm{j}$, excluding firm $\mathrm{j}$. It is important to mention here that we exclude firm $\mathrm{j}$ from city portfolio in order to avoid spurious results.

In order to check whether the co-movement in returns decrease as the distance between firm j's headquarter and other firms increase, we create a second portfolio of firms located in neighboring cities. Monthly return of neighboring city portfolio is calculated as follows:

$R_{\text {Neighbor }}=\frac{\sum_{k=1}^{N_{S}} R_{k}}{N_{S}}$

Where $\mathrm{N}_{\mathrm{S}}$ is the number of firms in neighboring cities and $\mathrm{R}_{\text {Neighbor }}$ is the monthly return of portfolio consisting of all firms headquartered in neighboring cities of the city where firm $\mathrm{j}$ is headquartered.

\subsection{Estimation procedure}

We measure co-movement of a stock using time-series sensitivity of its returns to returns of overall market index and to returns of same city portfolio. Our regression equation looks like the following:

$$
\left(R_{S}-R_{f}\right)=\alpha+\beta_{1}\left(R_{M}-R_{f}\right)+\beta_{2}\left(R_{\text {City }}-R_{f}\right)+\varepsilon
$$

The results from above regression equation are presented in Table 1 . The results not only demonstrate that co-movement of stock returns with same city portfolio is significant but also demonstrate that magnitude of this comovement is greater than the corresponding co-movement with market portfolio. We report that $\beta_{2}$ is significantly higher than $\beta_{1}$. Lesser co-movement with market portfolio can also be interpreted as an indication that firm's returns co-move less with returns of firms that are located farther away. Most of firms in market portfolio are, on average, headquartered in cities other than city of firm under consideration.

Table 1: Co-movement with city portfolio

\begin{tabular}{lc}
\hline & Coefficient \\
\hline Intercept & $0.003 * * *$ \\
Market Portfolio $\left(\boldsymbol{\beta}_{1}\right)$ & $0.126 * * *$ \\
City Portfolio $\left(\boldsymbol{\beta}_{2}\right)$ & $0.868 * * *$ \\
& \\
No. of Observations & 61424 \\
Adjusted $\mathbf{R}^{2}$ & 0.197 \\
$\boldsymbol{\beta}_{\mathbf{2}}-\boldsymbol{\beta}_{1}$ & $0.742 * * *$ \\
\hline
\end{tabular}

NOTE: The results significant at $10 \%$ significance level are followed by $*$, at $5 \%$ significance level by $* *$, and at $1 \%$ a significance level by***.

In order to check whether this co-movement decrease as distance between firm j's headquarter and other firms increase, we introduce another portfolio in Equation (3). This portfolio consists of firms from the neighboring cities. Our modified regression equation takes the following form: 


$$
\left(R_{S}-R_{f}\right)=\alpha+\beta_{1}\left(R_{M}-R_{f}\right)+\beta_{2}\left(R_{\text {City }}-R_{f}\right)+\beta_{3}\left(R_{\text {Neighbor }}-R_{f}\right)+\varepsilon
$$

The results from above regression equation are presented in Table 2. The results show that stock returns comove more with returns of same city portfolio than with returns of neighboring city portfolio and the market portfolio. Our results show that $\beta_{2}$ is significantly higher than $\beta_{1}$ and $\beta_{3}$. Given our assumption that market portfolio comprise of firms that are located, on average, farther away from firms of neighboring city, it is interesting to note that co-movement with market portfolio is the least followed by co-movement with neighboring cities portfolio and same city portfolio. It indicates that as distance increase co-movement tends to go down.

Table 2: Co-movement with city portfolio and neighboring cities portfolio

\begin{tabular}{lc}
\hline & Coefficient \\
\hline Intercept & $0.002 *$ \\
Market Portfolio $\left(\boldsymbol{\beta}_{1}\right)$ & $0.128^{* * *}$ \\
City Portfolio $\left(\boldsymbol{\beta}_{\mathbf{2}}\right)$ & $0.581^{* * *}$ \\
Neighboring Cities Portfolio $\left(\boldsymbol{\beta}_{3}\right)$ & $0.307 * * *$ \\
No. of Observations & 44586 \\
Adjusted $\mathbf{R}^{2}$ & 0.193 \\
$\boldsymbol{\beta}_{\mathbf{2}}-\boldsymbol{\beta}_{1}$ & \\
$\boldsymbol{\beta}_{3}-\boldsymbol{\beta}_{1}$ & $0.453 * * *$ \\
$\boldsymbol{\beta}_{\mathbf{2}}-\boldsymbol{\beta}_{3}$ & $0.179 * * *$ \\
\hline
\end{tabular}

NOTE: The results significant at $10 \%$ significance level are followed by $*$, at $5 \%$ significance level by $* *$, and at $1 \%$ a significance level by***.

\section{ROBUSTNESS OF RESULTS}

One of the reasons behind co-movement is information asymmetry. However, as information asymmetry reduces, co-movement should decreases. Since information environment improves with time, we divide our sample period into two periods. The first period ranges from 2003 to 2005 and the second from 2006 to 2007 . The choice of time period is arbitrary. The results from this analysis are presented in Table 3 and Table 4 . The results from Table 3 show that co-movement has slightly increased over the period of time. Furthermore, our results show reduction in co-movement with market over the period of time.

Table 3: Co-movement with city portfolio during different time periods

\begin{tabular}{lcc}
\hline & $\mathbf{2 0 0 3 - 2 0 0 5}$ & $\mathbf{2 0 0 6 - 2 0 0 7}$ \\
\hline Intercept & $0.005 * * *$ & $0.002^{* *}$ \\
Market Portfolio $\left(\boldsymbol{\beta}_{\mathbf{1}}\right)$ & $0.190^{* * *}$ & $0.073^{* * *}$ \\
City Portfolio $\left(\boldsymbol{\beta}_{2}\right)$ & $0.850^{* * *}$ & $0.874 * * *$ \\
& & 26935 \\
No. of Observations & 34489 & 0.164 \\
Adjusted $\mathbf{R}^{\mathbf{2}}$ & 0.211 & $0.801^{* * *}$ \\
$\boldsymbol{\beta}_{\mathbf{2}}-\boldsymbol{\beta}_{\mathbf{1}}$ & & $0.660^{* * *}$ \\
\hline
\end{tabular}

NOTE: The results significant at $10 \%$ significance level are followed by $*$, at $5 \%$ significance level by $* *$, and at $1 \%$ a significance level by***.

Table 4 confirms our previous findings that stock returns commove the most with returns of same city portfolio, followed by returns of neighboring cities portfolio and market portfolio. We report highest coefficient for $\beta_{2}$ followed by $\beta_{3}$ and $\beta_{1}$ for both groups. 
Table 4: Comovement with city portfolio and neighboring cities portfolio during different time periods

\begin{tabular}{lcc}
\hline & $\mathbf{2 0 0 3 - 2 0 0 5}$ & $\mathbf{2 0 0 6 - 2 0 0 7}$ \\
\hline Intercept & $0.002 *$ & $0.003 * *$ \\
Market Portfolio $\left(\boldsymbol{\beta}_{\mathbf{1}}\right)$ & $0.146^{* * *}$ & $0.103 * * *$ \\
City Portfolio $\left(\boldsymbol{\beta}_{\mathbf{2}}\right)$ & $0.556^{* * *}$ & $0.607 * * *$ \\
Neighboring Cities Portfolio $\left(\boldsymbol{\beta}_{\mathbf{3}}\right)$ & $0.338^{* * *}$ & $0.261^{* * *}$ \\
& & 19660 \\
No. of Observations & 24926 & 0.159 \\
Adjusted $\mathbf{R}^{\mathbf{2}}$ & 0.208 & $0.504 * * *$ \\
$\boldsymbol{\beta}_{\mathbf{2}}-\boldsymbol{\beta}_{\mathbf{1}}$ & & $0.158^{* * *}$ \\
$\boldsymbol{\beta}_{\mathbf{3}}-\boldsymbol{\beta}_{\mathbf{1}}$ & $0.410^{* * *}$ & $0.346^{* * *}$ \\
$\boldsymbol{\beta}_{\mathbf{2}}-\boldsymbol{\beta}_{\mathbf{3}}$ & $0.192^{* * *}$ & $0.218^{* * *}$ \\
\hline NOTE: The results significant at 10\% significance level are followed by $*$, at $5 \%$ significance level by $* *$, and at $1 \%$ a
\end{tabular}

\section{DISCUSSION OF RESULTS}

SENSEX 30 - market index in our paper - is composed of 30 largest and most actively traded stocks belonging to various sectors and representing around one-fifth of the market capitalization of the Bombay Stock Exchange. The index also includes India's top 5 conglomerates (Reliance, Tata, Wipro, Aditya Birla, and Bajaj). Most of firms in SENSEX 30 are nationally recognized firms, commanding confidence from national and foreign investors. However, the documented weak co-movements with SENSEX 30 refutes the arguments according to which investors are tempted to invest in the most visible and nationally recognized firms in emerging markets. Despite strong presence of subsidiaries from these nationally recognizable firms, we document low co-movement with SENSEX 30. We also show that this co-movement with SENSEX 30 is decreasing over time. Weak comovement with SENSEX 30 is an indicator of geographic segmentation as it implies that the most visible firms in India attract different investor profiles relative to the remaining traded equity. We believe that growth of SENSEX 30 during our sample period is fed by the enormous inflow of foreign investments in the Indian stock market. These foreign investors are more likely to invest in nationally visible conglomerates of SENSEX 30 rather than other firms.

Furthermore, relative strength of stocks' co-movement with same city and neighboring cities returns imply a local home bias behavior. Our results are in line with the findings of Grinblatt and Keloharju (2001) who show that investors, and more especially, the less sophisticated ones, exhibit a bias towards firms that are located near them. Given cultural, linguistic, and ethnic diversity in India, one should expect that local investor's choices are affected by more informal ways of information gathering. Our argument is complemented by Brown et al. (2004) who document presence of a publically traded firm in local community as determinant of stock market participation.

Using the three distance indices - market portfolio, same city portfolio, and neighboring cities portfolio we are also able to demonstrate the existence of headquarters' effect in India. This tendency of a firm's stock to comove more with stocks of firms located within the same area enhances the evidence on the role of geography in equity returns in emerging markets.

\section{CONCLUSION}

This paper confirms the presence of headquarter effect, an important aspect of recently documented role of geography in asset pricing, in an emerging market setting. We report that returns of firms tend to co-move with returns of other firms that are located in the same city. We also show that this co-movement tends to go down as the distance between firms increase. We report lower co-movement between returns of a firm and returns of firms located in the neighboring cities. Interestingly, our results show that co-movement is weakest with market index. Given that market index consists of firms that are located, on average, farther away from firms of neighboring city, weaker co-movement is an indication that investors tend to prefer stocks that they are more familiar with. 


\section{AUTHOR INFORMATION}

Omar Farooq, Department of Management, American University in Cairo, Egypt. E-mail: omar.farooq.awan@gmail.com (Corresponding author)

Molk Kadiri Hassani, School of Business Administration, Al Akhawayn University in Ifrane, Morocco

\section{REFERENCES}

1. Ahearne, A. G., Griever, W. L., and Warnock, F. E., (2004). Information Costs and Home Bias: an Analysis of US Holdings of Foreign Equities. Journal of International Economics, 62, pp. 313-336.

2. Anderson, C. W. and Beracha, E., (2006). Frothy Housing Markets and Local Stock Returns. Working Paper, University of Kansas.

3. Anderson, C. W. and Beracha, E., (2008). Robustness of the Headquarters-city Effect in Stock Returns. Journal of Financial Research, 31 (3), pp. 271-300.

4. $\quad$ Brown J., Ivkovich Z., Smith P. and Weisbenner S., (2005). Neighbors Matter: The Geography of Stock Market Participation. Working Paper, University of Illinois at Urbana-Champaign.

5. Chan, K., Covrig, V., and Ng, L., (2005). What Determines the Domestic Bias and Foreign Bias? Evidence from Mutual Fund Equity Allocations Worldwide. Journal of Finance, 60, pp. 1495-1534.

6. Coval, J. and Moskowitz, T., (1999). Home Bias at Home: Local Equity Preference in Domestic Portfolios. Journal of Finance, 54(6), pp. 2045-2073.

7. Coval, J. and Moskowitz, T., (2001). The Geography of Investment: Informed Trading and Asset Prices. Journal of Political Economy, 109, pp. 811-841.

8. Dahlquist, M., Pinkowitz, L, Stulz, R. M., and Williamson, R., (2003). Corporate Governance, Investor Protection, and the Home Bias. Journal of Financial and Quantitative Analysis, 38, pp. 87-110.

9. Davis, J. and Henderson, J. V., (2008). The Agglomeration of Headquarters. Regional Science and Urban Economics, 38 (5), pp. 445-460.

10. Feng, L. and Seasholes, M. S., (2002). Herding and Location. Working Paper, University of California at Berkeley.

11. Grinblatt, M. and Keloharju, M., (2001). How Distance, Language, and Culture Influence Stockholdings and Trades. Journal of Finance, 56, pp. 1053-1073.

12. Kang, J. K. and Stulz, R. M., (1997). Why is there a Home Bias? An Analysis of Foreign Portfolio Equity Ownership in Japan. Journal of Financial Economics, 46, pp. 3-28

13. Khanna, T. and Palepu, K., (2000). Is Group Affiliation Profitable in Emerging Markets? An Analysis of Diversified Indian Business Groups. Journal of Finance, 55 (2), pp. 867-891.

14. Pirinsky, C. and Wang, Q., (2006). Does Corporate Headquarters Location Matter for Stock Returns? Journal of Finance, 61, pp. 1991-2015. 